\title{
Heir to the Throne: Choice of the Replacement CEO After Unexpected CEO Turnovers
}

\author{
Mia L. Rivolta ${ }^{1}$ \\ ${ }^{1}$ Finance Department, Xavier University, Cincinnati, Ohio, USA \\ Correspondence: Mia L. Rivolta, Ph.D., Finance Department, Xavier University, 3800 Victory Parkway, Cincinnati, \\ Ohio 45207, USA.
}

Received: March 8, 2018

Accepted: March 22, 2018

Online Published: March 26, 2018

doi:10.5430/ijfr.v9n2p172

URL: https://doi.org/10.5430/ijfr.v9n2p172

\begin{abstract}
This paper analyzes firms' choice of replacement CEOs after unexpected CEO turnovers, and the impact of the replacement decision on shareholder wealth. More specifically, I investigate whether the selection of replacement CEOs from the board facilitates a smoother leadership transition. I find that while selecting replacement CEO from existing board members allows the company to quickly fill the CEO position, thereby reducing uncertainty and transitional costs (measured by new CEO turnover, senior management turnover and delay), it may not be beneficial to shareholders. I provide evidence that replacing departing CEO with a board member is negatively associated with stock performance for up to two years. This paper is a step forward towards the understanding of the roles boards play in the CEO succession and new CEO hiring process.
\end{abstract}

Keywords: CEO turnover, CEO succession, CEO labor market, board of directors

JEL Classification: G30, G34, J33, M51

\section{Introduction}

CEO succession planning is the process by which the board of directors prepares for the transition of leadership from one CEO to the next. It is cited as one of the most important yet challenging roles of the board of directors (Biggs, 2004). A lack of CEO succession planning is disruptive and increases business risk. (Note 1) Furthermore, it may be detrimental to shareholder wealth, in that firms encounter large costs associated with the disruption (Vancil 1987), especially in the event of the incumbent CEO's unexpected leave (e.g., due to illness, death, or sudden resignation) (Worell et al. 1986 and Behn et al 2006). The unanticipated retirement of Bank of America's CEO and Chairman Kenneth Lewis in late 2009 provides anecdotal evidence of the implications and manifestations of poor CEO succession planning. (Note 2) While Bank of America scrambled to appoint an inside executive, Brian Moynihan, having been rejected by 4 outside executives, its stock price fell $10 \%$, despite an $8 \%$ rise in the Dow Jones Industrial Average in the following month.

Despite the importance of ensuring a smooth CEO transition, literature on the process and the costs encountered during the transition has been scarce, possibly due to the fact that the detailed succession process is not directly observable. Most studies have focused on other aspects of CEO transition, such as the determinant of CEO turnover (Denis and Denis 1995, Parrino et al. 2003, Husonet al. 2004), the different types of CEO successions, for instance, whether the replacement CEO is hired from the inside or outside the company (Zhang and Rajagopalan 2004, 2010), and separation of CEO/chairman duality (Weisbach 1988, Parrino 1997, Agrawal et al. 2006). Very few studies (Krigman and Rivolta 2018, Rivolta 2018) documented the costs encountered in the CEO succession process, and how firms could reduce these costs to experience a smoother transition, particularly in unexpected CEO turnovers, where the disruption costs may be the highest. In addition, most studies on board of directors have focused on the role boards play in dismissing the incumbent CEOs (Denis and Denis 1995, Huson et al. 2004 and Del Guercio et al. 2008); a preliminary search has reveal that no published studies have examined the roles board of director play in the new CEO hiring process after an unexpected CEO departure.

In this paper I investigate the CEO replacement decision board of directors makes to minimize disruption, and the impact of this decision have on shareholder wealth after the CEO transition. More specifically, building upon the director expertise literature (Linck et al. 2008, Guner et al. 2008, Duchin et al 2010), I investigate whether 
replacement CEOs' existing board membership in the appointing firm prepares them to oversee the company when needed. Unexpected CEO turnover provides an exogenous setting that permits the examination of the impact of the CEO replacement decision on transitional costs and on shareholder wealth post succession. In such setting the departure of the CEO is neither the firm nor the executive's decision, and that information leak to the news of unexpected CEO deaths is unlikely.

I bifurcate replacement CEOs into board members and non-board members. Replacement CEOs board members are classified as the ones who have been on the appointing company's board for at least six months before the unexpected turnover. I examine the impact of replacement CEO board members on transitional costs in the succession process. The transitional costs are proxied by three measures: CEO turnover sensitivity (new CEO turnover within 18 months of succession), senior management turnover within one year of succession (Zhang and Rajagopalan 2004), and the delay between incumbent CEO departure and replacement CEO appointment (Behn et al 2006). Following Mian (2001) and Desai et al. (2006), I define senior management as president, COO and CFO. In addition, I examine the board's decision of replacement CEO on post succession stock performance within one month, three months, six months, one year and two years.

I find that when faced with unexpected CEO turnovers, firms tend to select replacement CEOs from inside the company and from existing board members. Out of the 112 unexpected CEO turnovers, 61 replacement CEOs (54\%) are existing board members. In addition, there seems to be a difference in firms that hire from the board than from those that do not. For instance, firms that hire existing board member replacement CEOs are more complex (larger, have higher growth and are in less homogeneous industries). This result may indicate that in order to reduce information asymmetry between the board and the replacement CEO in more complex firms, boards prefer to hire replacement CEOs who have the experience and expertise as directors and the familiarity with other board members.

The selection of a replacement CEO with board experience is associated with lower transitional costs overall, as measured by a significantly lower likelihood of senior management turnover one year after the succession and less delay between the incumbent CEO departure and new CEO appointment. There is, however, only a marginally significant relationship between new CEO turnovers within 18 months and replacement CEO board representation, which is consistent with existing management literature. For instance, Zhang and Rajagopalan 2008) argue that new CEO turnover is more likely after outside CEO successions. These results imply that appointing board members as replacement CEOs in unexpected turnover allows the board to quickly fill the position, hence reducing disruption in costs the succession process.

Last but definitely not least, I find that shareholders react negatively towards both announcements of the incumbent CEO's departure and new CEO's appointment in the subsample of firms who selected their replacement CEOs from board members. This finding suggests that investors may be concerned with a difficulty in replacing that the departing CEOs, and perceive that the choice of replacement CEO may negatively impact their future wealth. In addition, replacement CEOs selected from existing board members are associated with lower stock performance from one month to two years post succession, implying that the choice of replacement CEO board members may indeed harm shareholder wealth in the near future.

Overall, my results indicate that, in addition to monitoring and advising, another role board of directors can play is to oversee the company when needed. However, while selecting replacement CEO from existing board members may allow the company to quickly fill the CEO position, thereby reduce uncertainty and transitional costs; it may not be beneficial to shareholders. I argue that there can be two explanations for this result. On the one hand, the board may have exercised caution in selecting replacement CEOs from fellow board members, predicting that they will be the best fit for the job. However, due to the difficulty to replace the incumbent CEO, the new CEOs failed to reach the same level of performance (i.e. Steve Job may be difficult to replace), which leads to a worse stock performance. On the other hand, consistent with friendly board theory, instead of fulfilling the fiduciary duties of carrying an in-depth search for the best candidate for the job, the board has chosen to select those they have established relationship with on board, regardless of their competency, hence causing stock performance to decrease. It is difficult to pinpoint exactly which case is driving the results due to a lack of publically available information on firms' detailed succession planning process.

Nevetheless, this paper makes several contributions. First, in unexpected CEO turnovers, there exists greater information asymmetry between the board and potential CEO replacements than in voluntary expected turnovers. In voluntary CEO turnovers (i.e. planned retirement), the departing CEO can be involved in the succession planning process. Hence she is best informed about the potential CEO successors' qualifications (Vancil 1987). In addition, Brickley et al. (1996) argue that the opportunities in managerial labor market for retired CEOs are positively 
associated with their firms' performance. Therefore, retiring CEOs have the incentive to produce a successor who could continue their legacy or be even better than they were. However, in unexpected CEO turnovers, the information asymmetry between the board and potential CEO candidates is widened due to the fact that the departing CEO may not be able for consultation on the CEO replacement decisions. Hence, although there may be qualified non-board member candidates, directors may choose to hire those whom they have been working with as board members out of familiarity. Second, there may not be a grooming period after unexpected CEO turnovers. Vancil (1987) argue that a significant proportion of U.S. firms use relay or heir apparent succession - a type of orderly succession in which the departing CEO designates his or her successor well in advance - and work with the successors in order to pass the baton. Zhang and Rajagopalan (2006) argue that compared to other types of succession, relay succession has two advantages. First it provides the opportunity for departing CEO and the board to observe and to get familiar with the replacement. Second, the potential replacement CEO receives on-the-job training and gains firm specific knowledge. Naveen (2006) argues that more operationally complex firms (larger, more diversified firms, and firms in less homogeneous industries) benefit from relay succession. Yet, unexpected turnover takes away the necessary grooming period for potential successors if there is no succession plan in place, hence worsens the information asymmetry problem for the boards in selecting replacement CEOs.

The third importance of examining the CEO replacement decision and its impact is that it provides better insights of the roles boards play not only in monitoring and advising the company, but also in providing expertise to oversee the company when needed. Many studies have examined the board's monitoring and advising role in dismissing incompetent CEOs (e.g. Jensen Meckling 1976, Fama 1980, Shivadasani and Yermack 1999, Hwang and Kim 2009). This paper is a step forward towards the understanding of the roles boards play in the new CEO hiring decision.

The remainder of the paper is organized as follows. Section 2 discusses develops testable hypotheses. Section 3 describes the data. Section 4 (Section 5) presents univariate (multivariate) results on our main hypotheses. Section 6 concludes.

\section{Hypotheses Development}

Management literature has argued that the new CEO, especially those hired from the outside, typically have about 18 months to prove their competency to shareholders (Zhang 2008, Conlin 2009, and Zhang and Rajagopalan 2010), otherwise they will be dismissed. This argument is grounded in the information asymmetry theory that board of directors may have incomplete information about the CEO candidate. Hence, it is possible that the board may have hired the wrong executive and later on fires the new CEO to correct the mistake, which leads to greater new CEO turnover. This could be a huge cost to the company given the average severance pay the companies are offering to their executives (Note 3) (Huang 2011). I test whether the possibility of new CEO turnover is lower if the CEO candidate has been a member of the board before the succession. After an unexpected CEO turnover, board experience may be a substitute of the grooming period in voluntary expected turnover, creating opportunities for board members to observe the ability and expertise of the potential replacement CEOs, and decreasing the level of information asymmetry. I use Execucomp to identify new CEO turnover within 18 months of succession.

Hypothesis 1: New CEO turnover within 18 months of succession is less likely for successors with board experience prior to the turnover.

The second proxy of transitional cost is the senior management turnover within one year of CEO turnover. Prior literature has defined senior management as CEO, president, chairman, and vice-chairman (Desai, Hoger, and Wilkins 2006). In this paper, I also include Chief Financial Officers (CFOs) as part of the senior management. In contemporary U.S. corporations, CFOs are in charge of the design and application of the policy decisions related to the company's financial performance. Hence their effectiveness is of great importance to firm performance (Mian 2001). Senior management turnover could be a consequence of (1) dismissal initiated by the new CEO (2) voluntary resignation out of dissatisfaction of the new CEO (3) failed inside competition for the CEO position (4) natural retirement. In the first case, senior management dismissal is initiated by new CEOs, especially by outside successors, who prefer to select new senior management they have close connection with (Friedman \& Saul 1991). Second, senior management turnover could be a consequence of voluntary resignation due to dissatisfaction of the new outside successors, especially if those senior executives are strongly committed to the firms' past strategies and resist any dramatic changes initiated by the new successor (Helmich \& Brown 1972, Wiersema 1995). Third, senior management turnover could be a result of failed completion for the CEO position, which is unlikely in unexpected CEO turnovers. Last but not least, as mentioned in Shen and Cannella (2002), senior management turnover may simply due to ordinary retirement, although I argue that the last case may not be as common as the first three one year after the succession. According to the upper echelons theory, the entire management team, not the CEO alone, 
forms strategic decisions (Hambrick and Mason 1984, Hambrick, Cho and Chen 1996, Dooley and FryI 11 1999). Therefore, senior management change may impact the smoothness of CEO succession and firm performance during the transition. I expect that board experience may increase the familiarity betI en the successor and other senior management members; hence reduce the likelihood of senior management turnover in cases (1) and (2).

Hypothesis 2: There is less senior management turnover in firms whose successors have board experience prior to the turnover.

My third proxy for transitional costs is the delay between incumbent CEO departure and replacement CEO appointment. Unexpected CEO turnover create discontinuity in a company's daily operations, hence may create instability for the company and concerns among employees and investors. Some studies find that delay in naming a replacement CEO is associated with lower firm performance and income performance, and may impact shareholder wealth (Johnson et al. 1985, Worrel et al. 1986, and Behn et al. 2006). I calculate the number of days elapsed between the incumbent CEO departure and replacement CEO appointment, and expect that selecting replacement $\mathrm{CEO}$ from board members allows the firm to fill the CEO vacancy more quickly.

Hypothesis 3: There is less delay in firms whose successors have board experience prior to the turnover.

If the selection of replacement CEO from the board reduces information asymmetry and facilitates the board of the directors to choose the right type of CEO, then I should not only see less of a disruption in the transition, but also a continuity of performance post succession. Therefore the choice of replacement CEO with existing board membership should be associated with less negative or more positive market reaction and stock performance. Alternatively, the friendly board theory (Shivadasani and Yermack 1999, and Hwang and Kim 2009) may predict that instead of fulfilling the fiduciary duties of carrying an in-depth search for the best candidate for the job, the board chooses to select people whom they have established relationship with on board, or people that have had the ambition but no opportunity nor the ability to become CEO. Therefore the choice of replacement CEO with existing board membership may be associated with more negative or less positive market reaction and stock performance.

Hypothesis 4: The choice of replacement CEO with existing board membership is associated with less negative or more positive market reaction.

\section{Data and Sample Selection}

Table 1. Sample selection

\begin{tabular}{lllll}
\hline Year & $\begin{array}{l}\text { Total } \\
\text { Turnovers }\end{array}$ & $\begin{array}{l}\text { CEO } \\
\text { Planned } \\
\text { retirement }\end{array}$ & Forced & Unexpected \\
1997 & $107(5.72 \%)$ & $91(6.75 \%)$ & $11(2.68 \%)$ & $5(4.46 \%)$ \\
1998 & $152(8.13 \%)$ & $114(8.46 \%)$ & $27(6.59 \%)$ & $11(9.82 \%)$ \\
1999 & $151(8.07 \%)$ & $113(8.38 \%)$ & $31(7.56 \%)$ & $7(6.25 \%)$ \\
2000 & $200(10.70 \%)$ & $142(10.53 \%)$ & $47(11.46 \%)$ & $11(9.82 \%)$ \\
2001 & $201(10.75 \%)$ & $138(10.24 \%)$ & $46(11.22 \%)$ & $17(15.18 \%)$ \\
2002 & $156(8.34 \%)$ & $108(8.01 \%)$ & $39(9.51 \%)$ & $9(8.04 \%)$ \\
2003 & $151(8.07 \%)$ & $99(7.34 \%)$ & $43(10.49 \%)$ & $8(7.14 \%)$ \\
2004 & $142(7.59 \%)$ & $105(7.79 \%)$ & $24(5.85 \%)$ & $13(11.61 \%)$ \\
2005 & $170(9.09 \%)$ & $122(9.05 \%)$ & $40(9.76 \%)$ & $8(7.14 \%)$ \\
2006 & $142(7.59 \%)$ & $103(7.64 \%)$ & $32(7.80 \%)$ & $7(6.25 \%)$ \\
2007 & $160(8.56 \%)$ & $116(8.61 \%)$ & $37(9.02 \%)$ & $7(6.25 \%)$ \\
2008 & $138(7.38 \%)$ & $94(6.97 \%)$ & $33(8.05 \%)$ & $11(9.82 \%)$ \\
Total & $\mathbf{1 0 0 \% ( 1 8 7 0 )}$ & $\mathbf{1 0 0 \% ( 1 3 4 8 )}$ & $\mathbf{1 0 0 \% ( 4 1 0 )}$ & $\mathbf{1 0 0 \% ( 1 1 2 )}$ \\
\hline
\end{tabular}

This table shows the total number of CEO turnovers as well as the three different causes of turnovers during the sample period from 1996 to 2008. The initial sample is obtained from the Execucomp. For the purpose of this study, I only focus unexpected CEO turnovers. The final sample contains 112 unexpected CEO turnovers with 61 replacement CEOs have board representation at least six months before the succession, and 51 do not. 
In order to answer the question whether board experience reduces the cost of disruption in CEO succession process in unexpected CEO turnover, I use data from eight different sources. I first identify the initial sample of CEO turnovers during the period 1996-2008 from Execucomp, which covers S\&P 1500 firms. CRSP and Compustat provide stock return and accounting information. CEO successor board experience data are identified through the Investor Responsibility Research Center (IRRC) Director Legacy Database (Note 4). Institutional ownership information is obtained through Thomson Reuters Institutional Ownership Data. I hand fill in any observations where CEO appointment date or the date he/she joined the company is missing in Execucomp, for the purpose of identifying CEO tenure.

Table 1 shows the sample construction process. The initial sample contains 2,522 CEO turnovers identified from Execucomp during the period of 1996-2008. I use fiscal year as unit of time and merge the initial sample with CRSP and Compustat and exclude 36 observations with missing CRSP or Compustat data. I next merge the sample with IRRC Legacy Director Database by matching each annual shareholder meeting date for a firm with the fiscal year in which the meeting is held, and exclude 448 observations. I also exclude 43 observations in dual class firms. Last but not least, I exclude any observations where there was no actual CEO turnover; for instance, the change of CEO captured is due to the change of their last name, but the two observations are actually the same person. My final sample consists of 1,378 planned retirements, 410 forced and 112 unexpected CEO turnovers during the sample period 1996-2008.

For all 1,378 CEO turnovers, I use Factiva, Lexis Nexis and proxy statements to hand collect the following information: (1) CEO successor origin. This information is missing for some observations due to the missing data in Execucomp on the date the CEO joined the company. I follow Parrino (1997)'s definition on insider versus outsiders. Insiders are successors that have been with the company for at least one year prior to becoming CEO; and outsiders are successors that have been with the company for less than a year prior to becoming CEO. (2) Interim CEOs. Whether the news release states that the successor is an interim or permanent CEO. (3) Cause of turnover. I categorize the departure of the CEO into natural retirement, forced resignation, unexpected turnovers, M\&A activity, restructuring, proxy fight, and the separation of CEO/chairman duality. (4) The earliest announcement date of incumbent CEO departure and replacement CEO appointment. More often seen in voluntary expected turnovers, firms make the retirement and succession announcement at the same time. (5) Whether the replacement CEO has been the appointing company's board of director at least six months before the appointment announcement. (6) Cause of unexpected departure. Whether the unexpected departure is due to sudden death, illness, or is due to incumbent CEO being hired away either by a better company, or accepted a government job. (7) Whether the replacement CEO have had CEO experience before in other companies. (8) Whether the retiring CEO is the founder of the company, and whether the company is a family company. (9) The previous positions held by replacement CEOs.

Table 2. Firm, corporate governance, and CEO characteristics

\begin{tabular}{l} 
Firm characteristics \\
\hline Firm age \\
Mktcap (000) \\
ROA \\
R\&D intensity \\
Sale growth \\
Previous 1-year stock return \\
Industry adjusted ROA \\
Institutional ownership \\
Industry homogeneity \\
HHI \\
Governance characteristics \\
Board size \\
Independence \\
Fraction of outside CEOs \\
CEO/chairman duality \\
Founder CEO \\
CEO age60 \\
SOX
\end{tabular}

\begin{tabular}{lllll}
\hline $\begin{array}{l}\text { New } \\
\text { board member }(\mathrm{N}=51)\end{array}$ & $\begin{array}{l}\text { non-existing } \\
\text { member }(\mathrm{N}=61)\end{array}$ & \multicolumn{2}{l}{ New CEO existing board } & $\mathrm{H} 0: \mu 1=\mu 2$ \\
\hline Mean & Median & Mean & Median & \\
21 & 18 & 26 & 26 & $-4.862^{*}$ \\
5122.34 & 1670.76 & 16559.90 & 2460.66 & $-11437.6^{*}$ \\
$1.03 \%$ & $3.01 \%$ & $4.10 \%$ & $4.66 \%$ & -0.0307 \\
$15.20 \%$ & $0.00 \%$ & $3.33 \%$ & $0.00 \%$ & 0.119 \\
$6.07 \%$ & $7.75 \%$ & $13.61 \%$ & $8.56 \%$ & $-7.538^{*}$ \\
$-2.56 \%$ & $-2.95 \%$ & $5.37 \%$ & $-2.45 \%$ & -0.079 \\
$-0.46 \%$ & $1.14 \%$ & $2.23 \%$ & $2.42 \%$ & -0.027 \\
$63.82 \%$ & $100.00 \%$ & $58.81 \%$ & $64.40 \%$ & 0.050 \\
0.16 & 0.11 & 0.16 & 0.13 & 0.001 \\
0.61 & 0.50 & 0.59 & 0.53 & 0.019 \\
& & & & \\
10 & 9 & 10 & 10 & -0.684 \\
$72.91 \%$ & $77.78 \%$ & $61.08 \%$ & $62.50 \%$ & $0.118 * *$ \\
$10.20 \%$ & $5.56 \%$ & $9.39 \%$ & $9.09 \%$ & 0.008 \\
$1.96 \%$ & $0.00 \%$ & $6.56 \%$ & $0.00 \%$ & -0.046 \\
$3.92 \%$ & $0.00 \%$ & $13.11 \%$ & $0.00 \%$ & -0.092 \\
$1.96 \%$ & 0 & $27.87 \%$ & 0 & $-0.259 * *$ \\
$64.71 \%$ & 1 & $34.43 \%$ & 0 & $0.303 * *$
\end{tabular}


This table reports summary statistics of firm and corporate governance characteristics in firms with unexpected CEO turnovers and the mean difference between replacement CEO with and without board representation. All measures are as of year $t-1, t$ is the year of the unexpected CEO turnover. Market value of equity is calculated using end of the year closing price of equity to multiply common stock shares outstanding. Sales and total assets are directly obtained from Compustat, data item SALE and AT. ROA is the earnings before interest and taxes (EBIT) over total book assets (AT). I calculate both unjusted (un-tabulated) and industry-adjusted Tobin's q. The former is calculated as (total asset-book value of common equity + market value of common equity)/total assets. And industry-adjusted $Q$ is measured as firm Tobin's q minus median industry Tobin's q, using Fama and French (1997) 48-industry classification. Capital expenditure is directly identified from Compustat. $R \& D$ intensity is defined as research and development expenditure to sales. I calculate $R \& D$ intensity by taking the maximum value of 0 , or $R \& D$ expense from Compustat, whichever is larger is scaled by sales. Cash flow is measured by (Income before extraordinary items + Depreciation and amortization) to Sales. Firm age is the maximum number of years between CRSP listing age and Compustat listing age. CEO age is obtained from Execucomp as of the year of CEO turnover. I calculate the industry homogeneity proxy based on Parrino (1997). Sales based Herdindahl index (HHI) is defined as $\Sigma \mathrm{S}_{\mathrm{i}}{ }^{2} /\left(\Sigma \mathrm{S}_{\mathrm{i}}\right)^{2}$, where $\mathrm{S}_{\mathrm{i}}$ is the sales of segment $i$ (Naveen 2006). *,**,** represent significance level of 10\%, 5\%, and $1 \%$ in the two group mean comparison test, respectively.
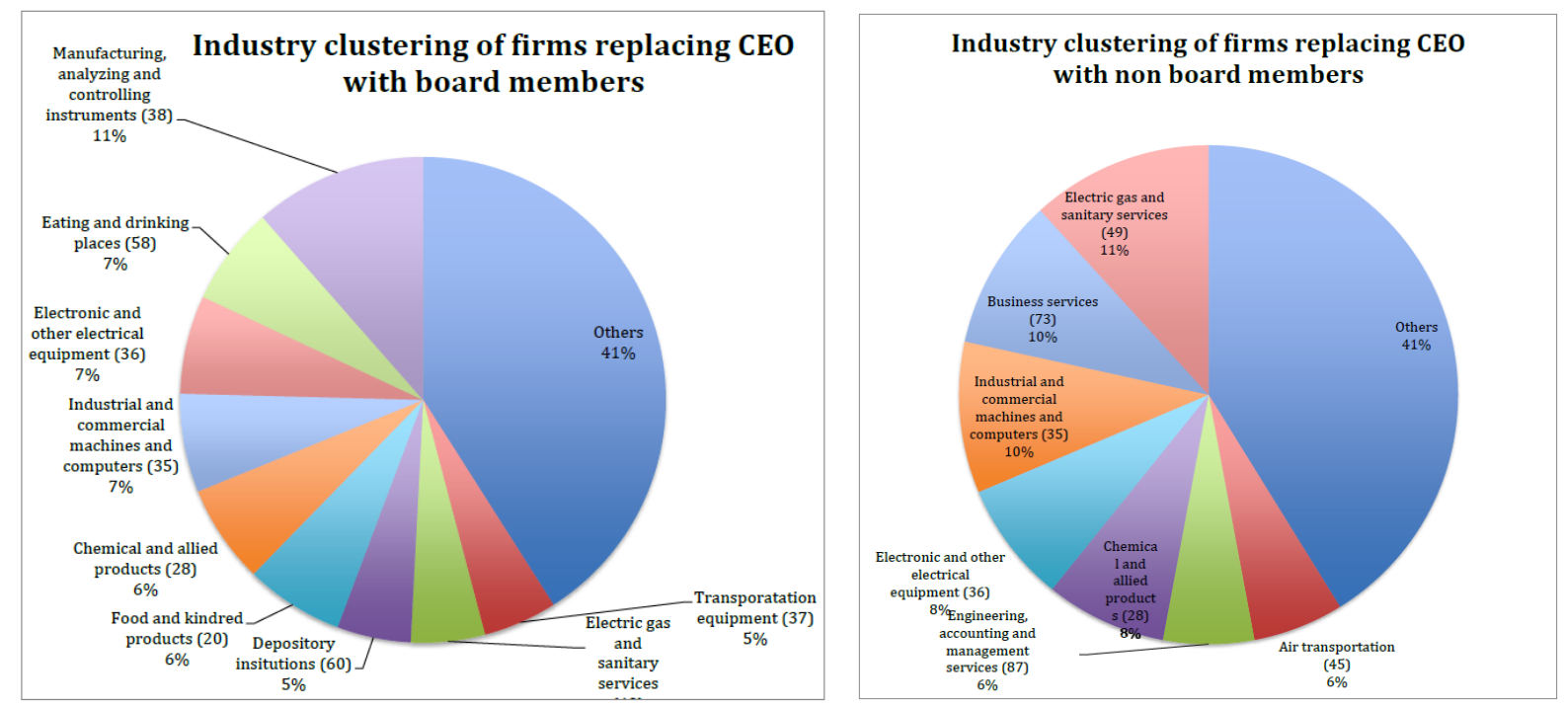

Figure 1A. Industry clustering
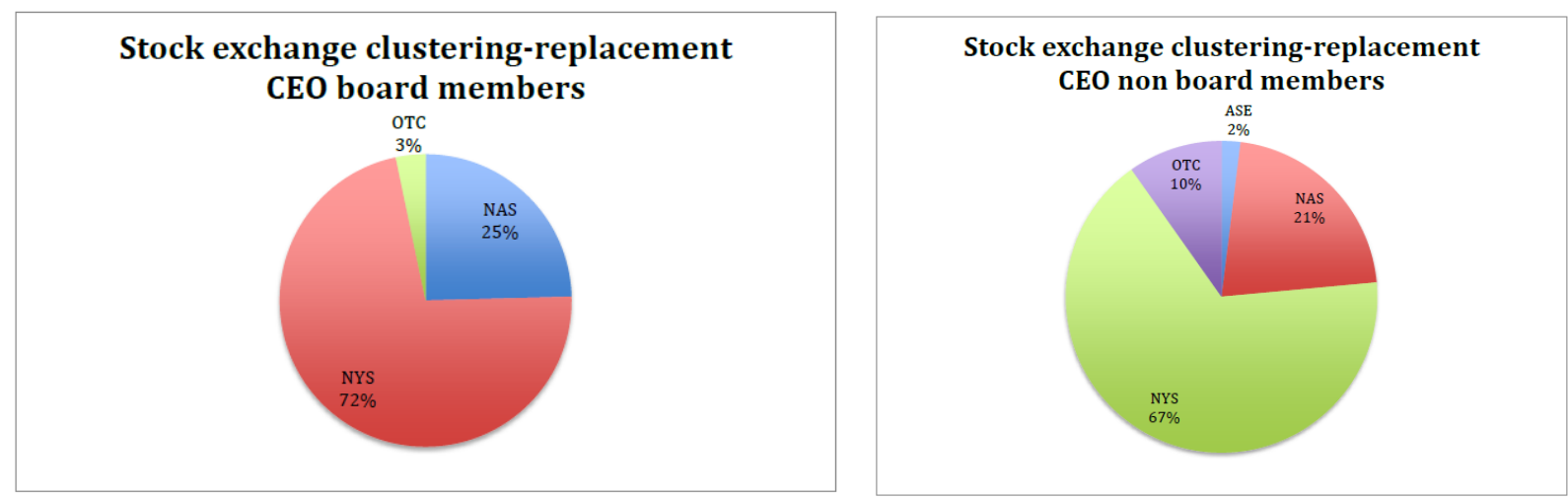

Figure 1B. Stock exchange clustering

Figure 1. Firm industry and stock exchange clustering based on replacement CEO board membership 
This figure shows the industry clustering (Figure 1A) and stock exchange clustering (Figure 1B) of firms whose replacement CEOs are existing board members versus non board members. I only report industry clustering of more than 5\%. I report the industry name, the percentage of sample firms clustered in that industry, and the 2-dit SIC code in parentheses.

After collecting data for the whole CEO turnover sample, I focus on the unexpected CEO turnovers. Table 2 shows that out of the 112 replacement CEOs, 61 are board members at least six months before the succession, and 51 are not. And the vast majority of the firms replace departing CEOs by insiders (82 insiders versus 30 outsiders). I then examine industry clustering and stock exchange clustering for the two subsample of firms: those who hired replacement CEO from existing board members and those did not. Figure 1A demonstrates the industry clustering and Figure 1B stock exchange clustering of the two subsamples. I report the industry name, the percentage of sample firms clustered in that industry, and the 2-dit SIC code in parentheses. I only report industry clustering of more than $5 \%$. For any industry clustering less than $5 \%$, I label it as "Others". For instance, in Figure 1A, "Others" consist of 28 different industries with average clustering of $1.46 \%$.

Table 3. Replacement CEO characteristics and transitional costs

Panel A

\begin{tabular}{llll}
\hline & Not on board & On board & Total \\
\cline { 2 - 4 } Frequency Outside & 23 & 7 & 30 \\
Percent & $20.54 \%$ & $6.25 \%$ & $26.79 \%$ \\
Row percent & $76.67 \%$ & $23.33 \%$ & \\
Column percent & $45.10 \%$ & $11.48 \%$ & 82 \\
Inside & 28 & 54 & $3.21 \%$ \\
& $25.00 \%$ & $48.21 \%$ & \\
& $34.15 \%$ & $65.85 \%$ & 112 \\
\hline Total & $54.90 \%$ & 88.52 & $100 \%$ \\
\hline
\end{tabular}

Panel B

\begin{tabular}{|c|c|c|c|c|c|}
\hline & \multicolumn{2}{|c|}{ board member $(\mathrm{N}=51)$} & \multicolumn{3}{|c|}{ board member $(\mathrm{N}=61)$} \\
\hline \multicolumn{6}{|l|}{ Replacement CEO characteristics } \\
\hline Delay & 47 & 0 & 33 & 0 & 14.24 \\
\hline First time CEO & $78.43 \%$ & $100 \%$ & $59.02 \%$ & $100 \%$ & $0.194 *$ \\
\hline CEO age & 50.83 & 51.00 & 56.41 & 54.50 & $-5.584 * * *$ \\
\hline Tenure & 4.11 & 3.80 & 4.54 & 3.50 & -0.436 \\
\hline Total compensation & 4759.13 & 2674.48 & 6472.45 & 3004.63 & -1713.3 \\
\hline Salary & 595.15 & 562.50 & 685.36 & 627.30 & -90.21 \\
\hline Bonus & 526.61 & 160.00 & 1034.53 & 300.00 & -507.9 \\
\hline CEO ownership (shares in thousands) & 154.60 & 65.09 & 2052.24 & 245.33 & $-1897.6^{*}$ \\
\hline New CEO turnover within 12 mons & $7.84 \%$ & $0.00 \%$ & $24.59 \%$ & $0.00 \%$ & $-0.167 *$ \\
\hline New CEO turnover within 18 mons & $9.80 \%$ & $0.00 \%$ & $27.87 \%$ & $0.00 \%$ & $-0.181 *$ \\
\hline Senior management turnover & $43.14 \%$ & $0.00 \%$ & $24.59 \%$ & $0.00 \%$ & $0.185^{*}$ \\
\hline Departure announcement CAR & $0.42 \%$ & $0.18 \%$ & $-2.96 \%$ & $-1.37 \%$ & $0.0337 * *$ \\
\hline Succession announcement CAR & $1.28 \%$ & $0.22 \%$ & $-2.87 \%$ & $-1.45 \%$ & $0.0415^{* * *}$ \\
\hline
\end{tabular}


This table shows boards' replacement CEO decisions and the comparison of transitional costs based on whether the new CEO is an existing board member. Panel A tabulates the origin and board experience of the new CEOs. Panel B shows univariate comparisons of mean and median of the values of firm and replacement CEO characteristics, followed by a mean difference test between subsamples of firms whose replacement CEO is an existing board member and those replacement CEO is not. Delay is the number of days between the outgoing CEO's departure announcement and the new CEO's appointment announcement. First time CEO is a binary variable that equals to 1 if the new CEO becomes the chief executive for the first time in his/her career and 0 otherwise. New CEO turnover is an indicator variable that equals to one if replacement CEO leaves the company within the time frame 12 months and 18 months, and 0 otherwise (Zhang and Rajagopalan 2008). Senior management turnover is an indicator variable that captures the departure of senior management, including President, COO and CFO. It equals to 1 if any of the senior management leaves the company one year after the new CEO's appointment and 0 otherwise. Departure announcement CAR is the cumulative abnormal returns one day around the outgoing CEO's departure announcement. Succession announcement CAR is the cumulative abnormal returns one day around the replacement CEO's appointment announcement. All other variable definitions are included in the Appendix. *, **, *** represent significance level of $10 \%, 5 \%$, and $1 \%$ in the two group mean comparison test.

Firms that replace CEO with board members are clustered in more heterogeneous industries, in which firm specific knowledge is not easily transferable, and production technologies and product markets firm compete in are not as comparable and similar as in more homogenous industries. Following Parrino (1997), I proxy industry homogeneity by calculating the mean partial correlation on industries returns in a regression of firm returns on market return and industry returns. Table 3 shows the industry homogeneity for industries that includes at least 35 firms at any given month. I first average the monthly stock returns for all firms in an industry (measured by the 2-digit Standardized Industrial Classification (SIC) code) to obtain the industry return index. Industry homogeneity is then calculated as the mean partial correlation coefficient on the industry returns. This proxy is larger for more homogeneous industries. As seen in Figure 1A, firm whose replacement CEOs are non-board members tend to cluster in more homogeneous industries. This may indicate that in order to replace the departing CEO in firms with higher industry heterogeneity, new CEOs have to have some sort of expertise in overseeing the company. Figure 1B shows that firms in the two subsamples have similar stock exchange clustering, with both having the largest proportion trading on NYSE.

I use Barber and Lyon (1996) event study methodology to calculate abnormal returns around incumbent CEO departure date and replacement CEO appointment date. I estimate the market model for 250 trading days before the announcement (i.e. starting 255 days before and ending 46 days before the announcement). CRSP value weighted index is used as market proxy. Then I obtain abnormal returns for days surrounding the announcements by subtracting expected returns from actual returns.

\section{Empirical Results}

\subsection{Univariate Analysis}

Following Parrino (1997), I control for industry homogeneity as a factor that may affect the choice of replacement CEOs in unexpected CEO successions. I first average the monthly stock returns for all firms in an industry (measured by the 2-digit Standardized Industrial Classification (SIC) code) to obtain the industry return index. Industry homogeneity is then calculated as the mean partial correlation coefficient on the industry returns in a two-factor market model that also includes a market return index. This proxy is larger for more homogeneous industries.

Table 4. Mean partial correlation industry homogeneity proxy values

\begin{tabular}{lll} 
SIC & Industry & Mean partial correlation \\
\hline 10 & Medal mining & 0.41206 \\
29 & Petroleum refining and related & 0.38874 \\
13 & Oil and Gas extraction & 0.36053 \\
44 & Water transportation & 0.35001 \\
57 & Home furniture and furnishing stores & 0.31531 \\
56 & Apparel and accessory stores & 0.30083 \\
45 & Air transportation & 0.29548 \\
53 & General merchandize stores & 0.27724
\end{tabular}




\begin{tabular}{|c|c|c|}
\hline 60 & Depository institutions & 0.27655 \\
\hline 26 & Paper and allied product & 0.27052 \\
\hline 70 & Hotels & 0.26154 \\
\hline 15 & Building construction-general & 0.25997 \\
\hline 49 & Electric gas and sanitary services & 0.25594 \\
\hline 25 & Furniture and fixture manufactures & 0.24326 \\
\hline 33 & Primary metal industries & 0.23616 \\
\hline 42 & Motor freight transportation/warehouse & 0.23450 \\
\hline 22 & Textile mill product & 0.23001 \\
\hline 67 & Holding and other investment offices & 0.22475 \\
\hline 23 & Apparel and other finished products-manufactures & 0.21612 \\
\hline 32 & Stone clay glass and concrete products & 0.21143 \\
\hline 63 & Life insurance & 0.20923 \\
\hline 54 & Food stores & 0.20091 \\
\hline 61 & Non depository credit institutions & 0.19577 \\
\hline 62 & Security and commodity brokers, etc. & 0.18710 \\
\hline 65 & Real estate & 0.18227 \\
\hline 37 & Transportation equipment & 0.17817 \\
\hline 58 & Eating and drinking places & 0.17762 \\
\hline 79 & Amusement and recreation services & 0.16157 \\
\hline 34 & Fabricated metal products & 0.16006 \\
\hline 80 & Health services & 0.15755 \\
\hline 78 & Motion pictures & 0.15122 \\
\hline 59 & Miscellaneous retails & 0.15031 \\
\hline 30 & Rubber and miscellaneous plastic products & 0.15008 \\
\hline 24 & Lumber and wood products & 0.14732 \\
\hline 27 & Printing, publishing and allied & 0.13226 \\
\hline 39 & Miscellaneous manufacturing & 0.13186 \\
\hline 48 & Communications & 0.12882 \\
\hline 87 & Engineering, accounting and management services & 0.11384 \\
\hline 36 & Electronic and other electrical equipment & 0.11256 \\
\hline 20 & Food and kindred products & 0.10925 \\
\hline 73 & Business services & 0.10186 \\
\hline 28 & Chemical and allied products & 0.09564 \\
\hline 51 & Wholesale trade-nondurable goods & 0.09139 \\
\hline 38 & Manufacturing, analyzing and controlling instruments & 0.07162 \\
\hline 50 & Wholesale trade-durable goods & 0.06703 \\
\hline 35 & Industrial and commercial machines and computers & 0.04892 \\
\hline Mean & & 0.20000 \\
\hline Median & & 0.19000 \\
\hline Standard deviation & & 0.08000 \\
\hline
\end{tabular}

Table 4 presents the descriptive statistics of firm, corporate governance and replacement CEO characteristics for the whole sample (Panel A), and the comparison between the two subsamples (Panel B). I report mean and median for both subsamples in Panel B. Columns 4 and 8 test whether the sample mean $(\mu)$ is significantly from 0 , and column 9 tests whether the two subsamples are drawn from the same distribution. Firm replacing their CEO with existing board members are larger, measured by market capitalization, older, have faster sales growth during the past three years, as well as better firm performance, measured by higher industry-adjusted Tobin's Q. This may indicate that the two subsamples of firms may require different talent in overseeing the company given the life cycle and stage firms are in. Firms whose replacement CEOs are board members experience significantly higher new CEO turnover 
within 18 months $(9.80 \%$ versus $27.87 \%)$. This result is contradictory to the prediction in Hypothesis 1 . However, senior management turnover one year after the succession and the delay between incumbent CEO departure and replacement CEO appointment are significant lower for firm who hire from the board, $43.14 \%$ versus $24.59 \%$ senior management turnover and 47 days versus 33 days in delay. This is consistent with Hypothesis 2 and 3. One possible reason why there exists a higher likelihood of new CEO turnover in firms who hire replacement CEO from the board may be the fact that the departing CEOs are more difficult to replace; hence, firm quickly hire a board member to oversee the company, while searching for a permanent CEO. Although contradictory to the prediction in Hypothesis 4 , the comparison of market reaction both towards incumbent CEO departure and replacement CEO appointment is consistent with the possible explanation above, in that shareholders barely have any reaction towards the succession in firms who do not hire from the board; yet react negatively at both announcement in firms who hire replacement CEO from the board.

Panel B also tabulates the comparison of corporate governance and replacement CEO characteristics between the two subsamples. Firms that replace their departing CEOs with board members have lower board independence and greater proportion of CEOs above age 60, which is consistent with the notion that the more insiders and experienced executives on board, the more likely one of the board members will be appointed CEO after unexpected turnovers. In addition, selecting CEOs from board members are more common pre-Sarbanes Oxley Act (SOX), since SOX requires all U.S. public companies to have a majority of independent board (Linck et al. 2008).

Overall, the results presented in Table 4 are consistent with idea that firms with harder to replace incumbent CEOs may intend to appoint replacement from existing board member. And this decision may be associated with lower transitional cost measured by senior management turnover and delay, however higher new CEO turnovers and more negative shareholder reactions. In the next section, I present the results of the multivariate analysis to further test these predictions.

\subsection{Multivariate Analysis}

Table 5. Correlations table

Panel A. Firm characteristic variable correlations

\begin{tabular}{|c|c|c|c|c|c|c|c|c|c|}
\hline Firm age & $\begin{array}{l}\text { Firm age } \\
1\end{array}$ & $\begin{array}{l}\text { Market } \\
\text { cap }\end{array}$ & Tobin's $Q$ & $R \& D$ & Capex & Prior lyy ret & $\begin{array}{l}\text { Institutional } \\
\text { own }\end{array}$ & $\begin{array}{l}\text { Industy } \\
\text { homogeneity }\end{array}$ & HHI \\
\hline Market cap & $\begin{array}{l}0.160 * * * \\
(0.000)\end{array}$ & 1 & & & & & & & \\
\hline Tobin's Q & $\begin{array}{l}-0.0891^{* * *} \\
(0.000)\end{array}$ & $\begin{array}{l}0.206 * * * \\
(0.000)\end{array}$ & 1 & & & & & & \\
\hline R\&D & $\begin{array}{l}-0.0532^{*} \\
(0.022)\end{array}$ & $\begin{array}{l}-0.00834 \\
(0.719)\end{array}$ & $\begin{array}{l}0.0305 \\
(0.188)\end{array}$ & 1 & & & & & \\
\hline Capex & $\begin{array}{l}-0.0285 \\
(0.226)\end{array}$ & $\begin{array}{l}-0.0269 \\
(0.253) \\
0.0772^{* *}\end{array}$ & $(0.001)$ & $\begin{array}{l}-0.0225 \\
(0.338)\end{array}$ & 1 & & & & \\
\hline Prior lyy ret & $\begin{array}{l}0.0483 * \\
(0.037)\end{array}$ & (0.001) & $\begin{array}{l}0.230 * * * \\
(0.000)\end{array}$ & $\begin{array}{l}-0.0251 \\
(0.280)\end{array}$ & $\begin{array}{l}0.00954 \\
(0.685)\end{array}$ & 1 & & & \\
\hline $\begin{array}{l}\text { Institutional } \\
\text { ownership } \\
\text { Induthy }\end{array}$ & $\begin{array}{l}-0.129 * * * \\
(0.000)\end{array}$ & $\begin{array}{l}-0.244 * * * \\
(0.000)\end{array}$ & $\begin{array}{l}-0.0464 \\
(0.057)\end{array}$ & $\begin{array}{l}0.0306 \\
(0.209)\end{array}$ & $\begin{array}{l}0.00183 \\
(0.941) \\
0.249 * *\end{array}$ & $\begin{array}{l}-0.0757 * * \\
(0.002)\end{array}$ & 1 & & \\
\hline $\begin{array}{l}\text { Idusty } \\
\text { homogeneity }\end{array}$ & $\begin{array}{l}0.100^{* * *} \\
(0.000)\end{array}$ & $\begin{array}{l}-0.0242 \\
(0.305)\end{array}$ & $\begin{array}{l}-0.168 * * \\
(0.000)\end{array}$ & $\begin{array}{l}0.0654^{* *} \\
(0.005)\end{array}$ & 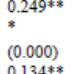 & $\begin{array}{l}0.0346 \\
(0.142)\end{array}$ & $\begin{array}{l}-0.0652^{* *} \\
(0.009)\end{array}$ & 1 & \\
\hline HHI & $\begin{array}{l}-0.238 * * * \\
(0.000)\end{array}$ & $\begin{array}{l}-0.148^{* * *} \\
(0.000)\end{array}$ & $\begin{array}{l}0.0782^{* *} \\
(0.001)\end{array}$ & $\begin{array}{l}0.129 * * * \\
(0.000)\end{array}$ & $\begin{array}{l}0.1348 * \\
(0.000)\end{array}$ & $\begin{array}{l}-0.0300 \\
(0.221)\end{array}$ & $\begin{array}{l}0.0805^{* *} \\
(0.002)\end{array}$ & $\begin{array}{l}0.00879 \\
(0.724)\end{array}$ & 1 \\
\hline
\end{tabular}

Panel B. Board and replacement CEO characteristics variable correlations

\begin{tabular}{|c|c|c|c|c|c|c|c|c|}
\hline Board size & $\begin{array}{l}\text { Board size } \\
1\end{array}$ & Independence & CEO_ag60 & Delay & $1^{\text {st }}$ time CEO & $\begin{array}{l}\text { Number of } \\
\text { tumovers }\end{array}$ & CEO age & CEO tenure \\
\hline Independence & $\begin{array}{l}0.0600^{* *} \\
(0.009)\end{array}$ & 1 & & & & & & \\
\hline CEO_ag60 & $\begin{array}{l}0.00739 \\
(0.749)\end{array}$ & $\begin{array}{l}-0.0409 \\
(0.077)\end{array}$ & 1 & & & & & \\
\hline Delay & $\begin{array}{l}-0.0397 \\
(0.086)\end{array}$ & $\begin{array}{l}0.0146 \\
(0.527)\end{array}$ & $\begin{array}{l}-0.0242 \\
(0.295)\end{array}$ & 1 & & & & \\
\hline First time CEO & $\begin{array}{l}0.0433 \\
(0.061)\end{array}$ & $\begin{array}{l}-0.0143 \\
(0.538)\end{array}$ & $\begin{array}{l}-0.190^{* * * *} \\
(0.000)\end{array}$ & $\begin{array}{l}-0.0397 \\
(0.086)\end{array}$ & 1 & & & \\
\hline Number of tumovers & $\begin{array}{l}0.00190 \\
(0.934)\end{array}$ & $\begin{array}{l}0.00570 \\
(0.805)\end{array}$ & $\begin{array}{l}0.170^{* * *} \\
(0.000)\end{array}$ & $\begin{array}{l}0.0931^{* * *} \\
(0.000)\end{array}$ & $\begin{array}{l}-0.0986^{* * *} \\
(0.000)\end{array}$ & 1 & & \\
\hline CEO age & $\begin{array}{l}0.110^{* * *} \\
(0.000)\end{array}$ & $\begin{array}{l}0.0253 \\
(0.275)\end{array}$ & $\begin{array}{l}0.619 * * * \\
(0.000)\end{array}$ & $\begin{array}{l}-0.0335 \\
(0.147)\end{array}$ & $\begin{array}{l}-0.203^{* * *} \\
(0.000)\end{array}$ & $\begin{array}{l}0.203^{* * *} \\
(0.000)\end{array}$ & 1 & \\
\hline CEO tenure & $\begin{array}{l}0.0788^{* * *} \\
(0.001)\end{array}$ & $\begin{array}{l}-0.181^{* * *} \\
(0.000)\end{array}$ & $\begin{array}{l}-0.129 * * * \\
(0.000)\end{array}$ & $\begin{array}{l}-0.0408 \\
(0.079)\end{array}$ & $\begin{array}{l}0.0589 * \\
(0.011)\end{array}$ & $\begin{array}{l}-0.353^{* * *} \\
(0.000)\end{array}$ & $\begin{array}{l}-0.130^{* * *} \\
(0.000)\end{array}$ & 1 \\
\hline
\end{tabular}


This table tabulates the correlation among firm and corporate governance variables. ***,**, and * indicate statistical significance at the $1 \%, 5 \%$, and $10 \%$ level, respectively. $p$-values are reported in the parentheses.

I first examine the correlation among the independent variables, as seen in Table 5. Panel A shows the correlation of firm character variables, and Panel B shows the correlation of board and replacement CEO characteristics variables. Older firms tend to be larger, have lower firm performance (measured by Tobin's Q), lower R\&D expense, in more homogeneous industries and are more likely to be diversified firms. However, in our sample, the larger firms have lower institutional ownership, which is opposite from what the existing literature predicts (Brickley et al. 1988, Woidtke 2002, and Parrino et al. 2003).

$$
\begin{aligned}
\text { New CEO turnover } & =\alpha_{0}+\alpha_{1} \text { On_board }+\alpha_{2} \text { Unexpected }+\alpha_{3} \text { First time CEO }+\alpha_{4} \text { Firm age }+\alpha_{5} \text { Ln }(\text { Total assets })_{t-1} \\
& +\alpha_{6} \text { ROA }_{t-1}+\alpha_{7} \text { Board size }+\alpha_{8} \text { Board independence }+\alpha_{9} \text { Replacement CEO age } \\
& +\alpha_{10} \text { Number of CEO turnovers }+\varepsilon i
\end{aligned}
$$

Senior management turnover ${ }_{t+1}=\beta_{0}+\beta_{1}$ On_board $+\beta_{2}$ Unexpected $+\beta_{3}$ First time CEO $+\beta_{4}$ Firm age

$$
\begin{aligned}
& \left.+\beta_{5} \text { Ln (Total assets) }\right)_{t-1}+\beta_{6} \text { ROA }_{t-1}+\beta_{7} \text { Board size } \\
& +\beta_{8} \text { Board independence }+\beta_{9} \text { Replacement CEO age } \\
& +\beta_{10} \text { Number of CEO turnovers }+\beta_{11} \text { Inside }+\varepsilon i
\end{aligned}
$$

Delay $=\lambda_{0}+\lambda_{1}$ On_board $+\lambda_{2}$ Unexpected $+\lambda_{3}$ First time CEO $+\lambda_{4}$ Firm age $+\lambda_{5} \operatorname{Ln}$ (Total assets) $)_{t-1}+\lambda_{6} R_{\text {ROA }} A_{t-1}$

$+\lambda_{7}$ Board size $+\lambda_{8}$ Board independence $+\lambda_{9}$ Replacement CEO age $+\lambda_{10}$ Number of CEO turnovers

$+\lambda_{11}$ Inside $+\lambda_{12} \mathrm{SOXe}+\lambda_{13}$ Sales growth $+\varepsilon i$

Market reaction of departing announcement $=\gamma_{0}+\gamma_{1}$ On_board $+\gamma_{2}$ Unexpected $+\gamma_{3}$ First time CEO $+\gamma_{4}$ Firm age

$+\gamma_{5}$ Ln (Total assets) $)_{t-1}+\gamma_{6}$ ROA $_{t-1}+\gamma_{7}$ Board size

$+\gamma_{8}$ Board independence $+\gamma_{9}$ Replacement CEO age

$+\gamma_{10}$ Number of CEO turnovers $+\varepsilon i$

Market reaction of apointment announcement $=\delta_{0}+\delta_{1}$ On_board $+\delta_{2}$ Unexpected $+\delta_{3}$ First time CEO $+\delta_{4}$ Firm age

$+\delta_{5} \operatorname{Ln}$ (Total assets) $)_{t-1}+\delta_{6} R O A_{t-1}+\delta_{7}$ Board size

$+\delta_{8}$ Board independence $+\delta_{9}$ Replacement CEO age

$+\delta_{10}$ Number of CEO turnovers $+\varepsilon i$

Post succession stock returns $=\gamma_{0}+\gamma_{1}$ On_board $+\gamma_{2}$ Unexpected $+\gamma_{3}$ First time CEO $+\gamma_{4}$ Firm age

\begin{tabular}{|c|c|c|c|c|c|c|}
\hline & Outgoing & CEO's & Departure & New & CEO's & Appointment \\
\hline & Announce & ent CAR & & Announ & ent CAR & \\
\hline & $(-1,0)$ & $(0,0)$ & $(0,1)$ & $(-1,0)$ & $(0,0)$ & $(0,1)$ \\
\hline Constant & 0.0118 & 0.0019 & -0.0614 & 0.0165 & -0.0023 & -0.0197 \\
\hline & $(0.800)$ & $(0.961)$ & $(0.324)$ & $(0.731)$ & $(0.950)$ & $(0.684)$ \\
\hline On_board & -0.0128 & $-0.0168 *$ & $-0.0387 * * *$ & -0.0162 & $-0.0209 * *$ & $-0.0466 * * *$ \\
\hline & $(0.288)$ & $(0.091)$ & $(0.002)$ & $(0.239)$ & $(0.046)$ & $(0.000)$ \\
\hline Death/illness & 0.0102 & 0.0033 & 0.0057 & 0.0142 & 0.0106 & 0.0175 \\
\hline & $(0.345)$ & $(0.712)$ & $(0.673)$ & $(0.227)$ & $(0.217)$ & $(0.102)$ \\
\hline First time CEO & 0.0172 & 0.0104 & 0.0246 & 0.0181 & 0.00921 & 0.0106 \\
\hline & $(0.147)$ & $(0.334)$ & $(0.123)$ & $(0.164)$ & $(0.375)$ & $(0.381)$ \\
\hline
\end{tabular}

$+\gamma_{5}$ Prior lyr return $+\gamma_{6}$ Board size $+\gamma_{7}$ Board independence

$+\gamma_{8}$ Replacement CEO age $+\gamma_{9}$ Number of CEO turnovers $+\varepsilon i$

Table 6. Effect of replacement CEO decisions on stock performance

Panel A. Market reaction towards departure of the outgoing CEO and the appointment of the replacing CEO 


\begin{tabular}{lllllll} 
Firm age & 0.0007 & 0.0006 & 0.0008 & 0.0007 & $0.0007^{*}$ & $0.0010^{* *}$ \\
& $(0.168)$ & $(0.158)$ & $(0.144)$ & $(0.206)$ & $(0.089)$ & $(0.027)$ \\
$\ln$ (total assets) & -0.0001 & -0.0001 & 0.0009 & -0.002 & -0.0009 & 0.0026 \\
& $(0.985)$ & $(0.826)$ & $(0.795)$ & $(0.522)$ & $(0.671)$ & $(0.410)$ \\
ROA $_{t-1}$ & $-0.0724^{*}$ & -0.0351 & 0.0373 & $-0.0850^{*}$ & -0.0568 & -0.0354 \\
& $(0.070)$ & $(0.347)$ & $(0.626)$ & $(0.081)$ & $(0.151)$ & $(0.553)$ \\
Board size & 0.0009 & 0.0015 & 0.0029 & 0.0019 & 0.0015 & 0.0025 \\
& $(0.637)$ & $(0.383)$ & $(0.220)$ & $(0.480)$ & $(0.420)$ & $(0.273)$ \\
Independence & -0.0015 & -0.0095 & -0.0043 & 0.0087 & 0.0086 & -0.0115 \\
& $(0.958)$ & $(0.666)$ & $(0.880)$ & $(0.751)$ & $(0.681)$ & $(0.683)$ \\
Replacement CEO age & -0.0009 & -0.0003 & 0.0002 & -0.0009 & -0.0004 & -0.0005 \\
& $(0.129)$ & $(0.527)$ & $(0.833)$ & $(0.187)$ & $(0.384)$ & $(0.405)$ \\
Number of turnovers & 0.0010 & -0.0045 & $-0.0078^{*}$ & 0.0011 & -0.0035 & -0.0064 \\
& $(0.816)$ & $(0.201)$ & $(0.092)$ & $(0.846)$ & $(0.434)$ & $(0.232)$ \\
$\mathrm{N}$ & 112 & 112 & 112 & 112 & 112 & 112 \\
$\mathrm{R}$-sq & 0.144 & 0.124 & 0.214 & 0.145 & 0.167 & 0.266 \\
\hline
\end{tabular}

Panel B. Post succession stock performance

\begin{tabular}{llllll}
\hline & $(0,30)$ & $(0,90)$ & $(0,180)$ & $(0,360)$ & $(0,720)$ \\
\cline { 2 - 6 } Constant & & & & & \\
& -0.00382 & 0.00384 & -0.388 & -0.822 & -0.701 \\
On_board & $(0.971)$ & $(0.989)$ & $(0.446)$ & $(0.308)$ & $(0.552)$ \\
& $-0.0613^{* *}$ & $-0.128^{* *}$ & $-0.221^{*}$ & $-0.452^{* *}$ & $-0.652^{* * *}$ \\
Death/illness & $(0.026)$ & $(0.037)$ & $(0.051)$ & $(0.017)$ & $(0.009)$ \\
& 0.0116 & 0.00663 & 0.0129 & -0.0362 & -0.123 \\
First time CEO & $(0.702)$ & $(0.929)$ & $(0.916)$ & $(0.846)$ & $(0.675)$ \\
& -0.00755 & -0.0412 & -0.0263 & 0.0197 & 0.00931 \\
Firm age & $(0.777)$ & $(0.528)$ & $(0.807)$ & $(0.915)$ & $(0.970)$ \\
& $0.00219 * *$ & $0.00495^{* *}$ & $0.00885^{* *}$ & 0.00981 & $0.0220^{* *}$ \\
Prior 1yr return & $(0.046)$ & $(0.032)$ & $(0.016)$ & $(0.113)$ & $(0.017)$ \\
& $0.0561^{*}$ & 0.0671 & 0.0564 & -0.329 & $-0.982^{* *}$ \\
Board size & $(0.064)$ & $(0.399)$ & $(0.673)$ & $(0.148)$ & $(0.011)$ \\
& 0.00296 & -0.00606 & -0.0106 & 0.00777 & -0.0213 \\
Independence & $(0.535)$ & $(0.504)$ & $(0.531)$ & $(0.789)$ & $(0.591)$ \\
& 0.0177 & -0.105 & -0.309 & -0.681 & -1.133 \\
Replacement CEO age & $(0.811)$ & $(0.562)$ & $(0.344)$ & $(0.177)$ & $(0.138)$ \\
Number of turnovers & -0.000672 & 0.00350 & $0.0140^{*}$ & $0.0270^{* *}$ & $0.0356^{* *}$ \\
N & $(0.689)$ & $(0.374)$ & $(0.050)$ & $(0.011)$ & $(0.026)$ \\
R-sq & -0.0124 & -0.0319 & -0.0396 & -0.0866 & -0.126 \\
& $(0.409)$ & $(0.264)$ & $(0.497)$ & $(0.325)$ & $(0.292)$ \\
& 111 & 111 & 111 & 111 & 111 \\
& 0.118 & 0.076 & 0.085 & 0.124 & 0.206 \\
\hline
\end{tabular}

Table 6 shows the results of the market reaction towards the outgoing CEO's departure and replacement CEO appointments (panel A), and the effect of replacing the CEO with existing board members on firms' stock performance for up to two years of the succession (Panel B). I use event study methodology to calculate the 
cumulative abnormal returns one day around the earliest announcement of outgoing CEO departure and replacement CEO appointment. The event windows are $(-1,0),(0,0)$ and $(0,1)$. In panel B, I measure a firm's stock performance by examining the post succession cumulative daily returns in 1 month ( 30 days), 3 months (90 days), 6 months (180 days), 12 months (360 days), 24 months (720 days). On_board is an indicator variable that equals to 1 if replacement CEO is an existing board member and 0 otherwise. Death/illness is also an indicator variable that equals to one if the old CEO departure is due to sudden death and illness, 0 if they are hired away. Number of turnovers is the total number of CEO turnover a firm experiences during the sample period 1996-2008. The definition of all other variables can be found in the Appendix. ***,**, and * indicate statistical significance at the $1 \%, 5 \%$, and $10 \%$ level, respectively. $p$-values are reported in the parentheses.

In this section, I examine the market reaction towards the outgoing CEO's departure and the replacement CEO's appointments (panel A), transitional costs around unexpected CEO succession (Panel B), and the effect of replacing the CEO with existing board members on firms' stock performance for up to two years of the succession (Panel C). I use event study methodology to calculate the cumulative abnormal returns around the earliest announcement of old CEO departure and replacement CEO appointment. Our event windows are $(-1,0),(0,0)$ and $(0,1)$. In panel B, I proxy transitional costs by using new CEO turnover within 18 months, senior management turnover within one year of the succession, and the delay between outgoing CEO's departure and replacement CEO's appointment. In panel C, I measure a firm's stock performance by examining the post succession cumulative daily returns in 1 month (30 days), 3 months (90 days), 6 months (180 days), 12 months (360 days), and 24 months (720 days). I use Probit model to test the effect of replacing departing CEO with an existing board member on new CEO turnover and senior management within one year of succession. OLS with robustness errors are used to test the effect of replacement CEO board representation on market reaction of the announcement, on delay between old CEO departure and replacement CEO appointment, and on post succession stock returns. On_board is an indicator variable that equals to 1 if replacement CEO is an existing board member and 0 otherwise. Unexpected is also an indicator variable that equals to one if the old CEO departure is due to sudden death and illness, 0 if they are hired away. Number of turnovers is the total number of CEO turnover a firm experiences during the sample period 1996-2008.

4.2.1 Market Reaction Surrounding the Incumbent CEO Departure and Replacement CEO Appointment Announcements

Table 6 panel A includes the abnormal returns by day from 1 day before to 1 day after both the departure and replacement announcements. Controlling for cross-sectional heteroscedasticity and serial correlation, abnormal returns on the day of the announcements and the day after are negative and statistically significant. Ceteris Paribus, the selection of a board member decrease the abnormal return by 17 (significant at 10\% level) and 38 basis points (significant at 5\% level) surrounding the incumbent CEO departure announcement, and by 21 (significant at 5\% level) and 47 basis points (significant at $1 \%$ level) surrounding the appointment announcement. However, abnormal returns are insignificant the day before the announcements, which indicates that leakage of unexpected CEO turnover is unlikely. Although this result is opposite to the prediction in Hypothesis 5, it is consistent with the idea that shareholders in firms who select replacement CEOs from existing board members may be concerned that the departing CEOs are difficult to replace. And the replacements may not be as competent for the job as the departed CEO. Another possible explanation for shareholders' negative reaction is that facing unanticipated CEO turnover, board may not be fulfilling their fiduciary duty of doing an in-depth search on the replacements; instead, they just quickly appointed a fellow board member. However, it is difficult to pinpoint which argument is more accurate.

\subsubsection{The Effect of Selecting Replacement CEO From the Board on Transitional Costs}

Panel B shows the impact of replacement CEO board representation on the three proxies of transitional costs: new CEO turnover (model 1), senior management turnover within one year (model 2) and delay (model 3). The dependent variables are binary in the first two models, hence I use Probit model and calculate the marginal effect for a change in on_board from 0 to 1. And I use OLS on the effect of replacement CEO representation on Delay, controlling for cross-sectional heteroscedasticity and serial correlation. The marginal effect of On_board on new CEO turnover is significant with correlation coefficient of 0.703 on new CEO turnover within 18 months at the $10 \%$ level. Lack of prior CEO experience and an increase of board size reduce the likelihood of new CEO turnover, both effects are significant at the $10 \%$ level. These findings are consistent with the idea that it may be more difficult to reach an agreement on firing the new CEO in a bigger board, and that the board is more forgiving towards first-time CEOs when they just picked up the baton. 
Table 7. Effect of replacement CEO decisions on other transitional costs

\begin{tabular}{|c|c|c|c|}
\hline & New CEO turnover & Senior management turnover & Delay \\
\hline \multirow[t]{2}{*}{ Constant } & -1.413 & 0.234 & $84.72 *$ \\
\hline & $(0.400)$ & $(0.856)$ & $(0.059)$ \\
\hline \multirow[t]{2}{*}{ On_board } & $0.703 *$ & $-0.657 * *$ & $-19.90 *$ \\
\hline & $(0.095)$ & $(0.039)$ & $(0.062)$ \\
\hline \multirow[t]{2}{*}{ Death/illness } & 0.507 & -0.201 & $22.03 * *$ \\
\hline & $(0.239)$ & $(0.473)$ & $(0.048)$ \\
\hline \multirow[t]{2}{*}{ First time CEO } & $-0.740 *$ & 0.162 & $17.89^{* *}$ \\
\hline & $(0.060)$ & $(0.593)$ & $(0.043)$ \\
\hline \multirow[t]{2}{*}{ Firm age } & -0.002 & -0.00225 & -0.190 \\
\hline & $(0.898)$ & $(0.849)$ & $(0.626)$ \\
\hline \multirow[t]{2}{*}{$\ln$ (total assets) } & 0.124 & $-0.172 *$ & 0.0264 \\
\hline & $(0.336)$ & $(0.089)$ & $(0.992)$ \\
\hline \multirow[t]{2}{*}{$\mathrm{ROA}_{t-1}$} & -0.005 & -0.608 & -61.37 \\
\hline & $(0.997)$ & $(0.588)$ & $(0.186)$ \\
\hline \multirow[t]{2}{*}{ Board size } & $-0.189 *$ & 0.0583 & -0.0317 \\
\hline & $(0.063)$ & $(0.307)$ & $(0.989)$ \\
\hline \multirow[t]{2}{*}{ Independence } & -0.538 & -0.847 & -27.79 \\
\hline & $(0.616)$ & $(0.298)$ & $(0.339)$ \\
\hline \multirow[t]{2}{*}{ Replacement CEO age } & 0.000 & 0.0227 & -0.598 \\
\hline & (0.994) & $(0.208)$ & $(0.338)$ \\
\hline \multirow[t]{2}{*}{ Number of turnovers } & $0.551 * * *$ & -0.0563 & 8.276 \\
\hline & $(0.001)$ & $(0.647)$ & $(0.111)$ \\
\hline \multirow[t]{2}{*}{ Inside } & & -0.0734 & $-49.05 * * *$ \\
\hline & & $(0.817)$ & $(0.003)$ \\
\hline \multirow[t]{2}{*}{ SOX } & & & 2.976 \\
\hline & & & $(0.736)$ \\
\hline \multirow[t]{2}{*}{ Sales growth } & & & -0.143 \\
\hline & & & $(0.691)$ \\
\hline $\mathrm{N}$ & 112 & 112 & 104 \\
\hline pseudo R-sq or R-sq & 0.285 & 0.087 & 0.378 \\
\hline
\end{tabular}

Table 7 tabulates the effect of replacement CEO decisions on other transitional costs. I proxy transitional costs by using new CEO turnover within 12 months and 18 months, senior management turnover within one year of the succession, and the delay between outgoing CEO departure and replacement CEO appointment. I use Probit model to test the effect of replacing departing CEO with an existing board member on new CEO and senior management turnover within one year of succession. OLS with robustness errors are used to test the effect on market reaction of the announcement and on delay between old CEO departure and replacement CEO appointment. On_board is an indicator variable that equals to 1 if the replacement $\mathrm{CEO}$ is an existing board member and 0 otherwise. Death/illness is an indicator variable that equals to one if the outgoing CEO's departure is due to sudden death and illness, 0 if they are hired away. Number of turnovers is the total number of CEO turnover a firm experiences during the sample period 1996-2008. The definition of all other variables can be found in the Appendix. The definition of all other 
variables can be found in the Appendix.***,**, and * indicate statistical significance at the $1 \%, 5 \%$, and $10 \%$ level, respectively. $p$-values are reported in the parentheses.

Consistent with Hypotheses 2 and 3, replacement CEO board representation is associated with lower likelihood of senior management turnover and less delay. More specifically, selecting a board member as the new CEO reduces the likelihood of senior management turnover by $65.7 \%$, which may indicate that there is less information asymmetry between senior management and the new CEO had she/he has been a board member. Other executives may be more aware of the characteristics and competency of the new CEO. This familarity reduces the friction and likelihood of turnover due to disagreement in firm strategy and managing styles.

I also find that selecting replacement CEO from board members reduces the time it takes to fill up the position, which is consistent with Hypothesis 4 and the descriptive statistics earlier. I bifurcate the reasons for unexpected CEO turnover into sudden death and illness, as well as green pasture, in which case the incumbent CEOs are hired away by bigger better firms, and I use an indicator variable that equals to 1 if the cause of turnover is death or illness, and 0 if greener pasture. The result shows that death and illness are associated with a longer delay, significant at 5\% level than greener pasture. I argue that this longer delay in appointing a new CEO may be caused by a bigger shock associated with death of the CEO rather than them being hired away. In addition, I find that appointing replacement CEO from firm insiders is associated with less delay.

\subsubsection{Post Succession Stock Returns}

Panel C demonstrates the abnormal returns within 30, 90, 180, 360 and 720 days after the succession. Ceteris paribus, all abnormal returns are statistically significant and negatively associated with the selection of replacement CEO from the board. And it seems like the magnitude of this inverse relationship is higher in the longer term, which consistent with the argument that it may take a while for the stock and firm performance to reflect CEO ability (Graffin et al. 2012, working paper). This result, again, is contradictory to the prediction in Hypothesis 5, yet is consistent with the notion that although the appointment of a board member as replacement CEO allows the company to quickly fill the position and reduce transitional costs, it may not be beneficial to shareholder wealth.

Firm age is positively associated with post succession stock returns. Older firms having better stock performance facing unexpected CEO turnovers may imply that older firms have the maturity and resources to deal with an exogenous shock than younger firms. Graffin et al. (2012) argue that executive age can be a proxy for their working experience. If this is true, then on average, more experienced replacement CEOs are associated with better stock performance in longer terms (from 6 months up to 2 years), significant at the 5\% level.

\section{Conclusion}

In this paper, I examine the roles board of directors can play in CEO succession planning by examining CEO replacement decisions after an unexpected CEO turnover, and the impact of this decision on shareholder wealth. Overall, my results indicate that, in addition to monitoring and advising, another role board of directors can play is to oversee the company when needed. However, while selecting replacement CEO from existing board members may allow the company to quickly fill the CEO position, thereby reducing uncertainty and transitional costs (measured by new CEO turnover, senior management turnover and delay), it may not be beneficial to shareholders. I provide evidence that replacing departing CEO with a board member is negatively associated with stock performance for up to two years. I argue that there could be two explanations for this observation. On the one hand, the board may have exercised caution in selecting replacement CEOs from fellow board members, predicting that they will be the best fit for the job. However, due to the difficulty to replace the incumbent CEO, the new CEOs failed to reach the same level of performance, which leads to a worse stock performance. On the other hand, consistent with friendly board theory, instead of fulfilling the fiduciary duties of carrying an in-depth search for the best candidate for the job, the board has chosen to select those they have established relationship with on board, regardless of their competency, hence causing stock performance to decrease. It is difficult to pinpoint which explanation is more accurate without detailed succession planning information, which is not directly observable. Nevertheless, I provide some of the first evidence on the link between replacement CEO decisions and the transitional cost in the CEO labor market. My findings show that boards need not to panic and rush to name a permanent CEO when faced with a lack of leadership. Since board members can fill the CEO position to reduce uncertainty, it may be beneficial for boards to appoint an existing member as the interim CEO and take their time to make the right CEO replacement decisions. 


\section{Acknowledgement}

I thank Tracie Woidtke, Mike Ehrhardt, Andy Puckett, and other participants at the research seminar at the University of Tennessee for their helpful comments and suggestions.

\section{References}

Adams, R. B., Almeida, H., \& Ferreira, D. (2005). PoI rful CEO and their impact on corporate policies. Review of Financial Studies, 18(4), 1403-1432. https://doi.org/10.1093/rfs/hhi030

Adams, R. B., \& Ferreira, D. (2007). A theory of friendly boards. The Journal of Finance, 62, 217-250. https://doi.org/10.1111/j.1540-6261.2007.01206.x

Agrawal, A., Knoeber, C., \& Tsoulouhas, T. (2006). Are Outsiders Handicapped in CEO Successions? Journal of Corporate Finance. https://doi.org/10.1016/j.jcorpfin.2004.04.005

Bacon, J., \& Brown, J. (1974). Corporate directorship practices: role, selection, and legal status of the board. A joint research report, The Conference Board and the American Society of Corporate Secretaries, Inc., New York, NY.

Baranchuk, N., \& Dybvig, P. H. (2009). Consensus in diverse corporate boards. Review of Financial Studies, 22, 715-747. https://doi.org/10.1093/rfs/hhn052

Barber, B. M., \& Lyon, J. D. (1996). Detecting abnormal performance. The empirical poI $r$ and specification of test statistics. Journal of Financial Economics, 41, 359-399. https://doi.org/10.1016/0304-405X(96)84701-5

Booth, J. R., \& Deli, D. N. (1996). Factors affecting the number of outside directorships held by CEOs. Journal of Financial Economics, 40, 81-104. https://doi.org/10.1016/0304-405X(95)00838-6

Booth, J. R., \& Deli, D. N. (1999). On executives of financial institutions as outside directors. Journal of Corporate Finance, 5, 227-250. https://doi.org/10.1016/S0929-1199(99)00004-8

Borokhovich, K., Parrino, R., \& Trapani, T. (1996). Outside Directors and CEO Selection. Journal of Financial and Quantitative Analysis, 31, 337-355. https://doi.org/10.2307/2331395

Brickley, J., Coles, J., \& Jarrell, G. (1997). Leadership Structure: Separating the CEO and Chairman of the Board. Journal of Corporate Finance, 3, 189-220. https://doi.org/10.1016/S0929-1199(96)00013-2

Brickley, J. A., Linck, J. S., \& Coles, J. L. (1998). What happens to CEOs after they retire? New evidence on career concerns, horizon problems, and CEO incentives. Journal of Financial Economics, 52, 341-77. https://doi.org/10.1016/S0304-405X(99)00012-4

Byrne, John, William A., Symonds, C., \& Siler, Julia F. (1991). CEO disease: Egoism can breed corporate disaster, and the malady is spreading. Business Iek, April 1, 52-60.

Cannella, A., Jr., \& Lubatkin, M. (1993). Succession as a sociopolitical process: Internal impediments to outsider selection. Academy of Management Journal, 36, 763-793. https://doi.org/10.2307/256758

Coles, J. L., Daniel, N. D., \& Naveen, L. (2008). Boards: does one size fit all?. Journal of Financial Economics, 82, 329-356. https://doi.org/10.1016/j.jfineco.2006.08.008

Cowling, M. (2007). Small firm CEOs and outside directorships: Tenure, demonstration and synergy effect. Working paper.

Davis, G. (1996). The significance of board interlocks for corporate governance. Corporate Governance, 4(3), 154-159. https://doi.org/10.1111/j.1467-8683.1996.tb00144.x

Davis, S., \& Nosal, D. (2009). Smart planning for CEO succession. The Corporate Board.

De Long, J. B. (1991). Did J.P. Morgan's men add value? An Economist's perspective on financial capitalism, In Inside the business enterprise: Historical perspectives on the use of information. In Peter Temin (Ed.), National Bureau of Economic Research Conference Report. Chicago: University of Chicago Press.

Denis, D., \& Denis, D. (1995). Performance changes following top management_dismissals. Journal of Finance, 50, 1029-1057. https://doi.org/10.1111/j.1540-6261.1995.tb04049.x

Duchin, R., Matsusaka, J. G., \& Ozbas, O. (2010). When are outside directors effective?. Journal of Financial Economics, 96, 195-214. https://doi.org/10.1016/j.jfineco.2009.12.004 
Fahlencrach, R., Minton, B., \& Pan, C. (2010). Former CEO directors: lingering CEOs or valuable resources?. Working paper.

Fahlencrach, R., Low, A., \& Stulz, R. (2010). Why do firms appoint CEOs as outside directors?. Journal of Financial Economics, 97, 12-32. https://doi.org/10.1016/j.jfineco.2010.01.003

Fama, E. F., \& Jensen, M. C. (1983). Separation of ownership and control. Journal of Law and Economics, 26, 301-325. https://doi.org/10.1086/467037

Fama, E. F. (1980). Agency problem and the theory of the firm. Journal of Political Economy, 88, 288-307. https://doi.org/10.1086/260866

Ferris, S. P, \& Jagannathan, M. (2001). The incidence and determinants of multiple corporate directorships. Applied Economics Letters, 8(1), 31-35. https://doi.org/10.1080/135048501750041259

Ferris, S. P., Jagannathan, M., \& Pritchard, A. C. (2003). Too busy to mind the business? Monitoring by directors with multiple board appointments. The Journal of Finance, 58, 1087-1112. https://doi.org/10.1111/1540-6261.00559

Fich, E. M., \& Shivdasani, A. (2006). Are Busy Boards Effective Monitors?. The Journal of Finance, 61, 689-724. https://doi.org/10.1111/j.1540-6261.2006.00852.x

Fich, E. M. (2005). Are some outside director better than others? Evidence from Director Appointments by Fortune 1000 Firms. The Journal of Business, 78(5). https://doi.org/10.1086/431448

Gilson, S. (1990). Bankruptcy, boards, banks, and blockholders. Journal of Financial Economics, 27, 355-387. https://doi.org/10.1016/0304-405X(90)90060-D

Guner, A. B., Malmendier, U., \& Tate, G. (2008). Financial expertise of directors. Journal of Financial Economics, 88, 323-354. https://doi.org/10.1016/j.jfineco.2007.05.009

Harris, M., \& Raviv, A. (2008). A theory of board control and size. Review of Financial Studies, 21(4), 1797-183. https://doi.org/10.1093/rfs/hhl030

Hermalin, B. E., \& Isbach, M. S. (2003). Endogenously chosen boards of directors and their monitoring of the CEO. American Economic Review, 88, 96-118.

Hwang, B., \& Kim, S. (2009, July). It pays to have friends. Journal of Financial Economics, 93, 138-158. https://doi.org/10.1016/j.jfineco.2008.07.005

Iisbach, M. (1988). Outside directors and CEO turnover,. Journal of Financial Economics, 20, 431-60. https://doi.org/10.1016/0304-405X(88)90053-0

Jensen, M. C., \& Meckling, W. H. (1976). Theory of the Firm: Managerial Behavior Agency Costs and Ownership Structure. Journal of Financial Economics, 3, 305-360. https://doi.org/10.1016/0304-405X(76)90026-X

Krigman, L., \& Rivolta, M. L. (2018). Can non-CEO inside directors add value? Evidence from unplanned CEO turnovers. Working paper

Lee, S., \& Persson, P. (2010). Authority versus loyalty: social incentives and modes of governance. Working paper, 2010 WFA Conference.

Linck, J. S., Netter, J. M., \& Yang, T. (2009). The Effects and Unintended Consequences of the Sarbanes-Oxley Act on the Supply and Demand for Directors. Review of Financial Studies, 22, 3297-3323. https://doi.org/10.1093/rfs/hhn084

Lorsch, J., \& MacIver, E. (1989). Pawns or potentates: The reality of America's corporate boards. Boston: Harvard Business School Press.

Mace, M. (1986). Directors: Myth and reality. Boston: Harvard Business School Press.

Malmendier, U., \& Tate, G. (2005). Superstar CEOs. Working paper. https://doi.org/10.2139/ssrn.709861

Mian, S. (2001). On the choice and replacement of CFOs. Journal of Financial Economics, 60, 143-175. https://doi.org/10.1016/S0304-405X(01)00042-3

Morck, R., Shleifer, A., \& Vishny, R. W. (1989). Alternative mechanism for corporate control. The American Economic Review, 79, 842-852. 
Parrino, R. (1997). CEO Turnover and Outside Succession: A Cross-Sectional Analysis. Journal of Financial Economics, 46, 165-197. https://doi.org/10.1016/S0304-405X(97)00028-7

Parrino, R., Sias, R., \& Starks, L. (2003). Voting with their feet: institutional ownership changes around forced CEO turnover. Journal of Financial Economics, 68, 3-46. https://doi.org/10.1016/S0304-405X(02)00247-7

Perry, T., \& Peyer, U. (2005). Board seat accumulation by executives: A shareholder's perspective. The Journal of Finance, 60, 2083-2123. https://doi.org/10.1111/j.1540-6261.2005.00788.x

Rivolta, M. L. (2018). Worth the wait? Delay in CEO succession after unplanned CEO departures. Journal of Corporate Finance, forthcoming.

Salas, J. M. (2010). Entrenchment, governance and the stock price reaction to sudden executive deaths. Journal of Business and Finance, 34, 656-666. https://doi.org/10.1016/j.jbankfin.2009.09.002

Shen, I. I., \& Cannella, A. A. Jr. (2002). Revisiting the performance consequences of CEO succession: the impacts of successor type, post succession senior executive turnover, and departing CEO tenure. The Academy of Management Journal, 45(4), 717-733. https://doi.org/10.2307/3069306

Shivdasani, A., \& Yermack, D. (1999). CEO Involvement in the Selection of New Board Members: An Empirical Analysis. Journal of Finance, 54, 1829-1853. https://doi.org/10.1111/0022-1082.00168

Worrell, D. L., Davidson III, W. N., Chandy, P. R., \& Garrison, S. L. (1986). Management turnover through deaths of key executives: effects on investor Ialth. Academy of Management, 29, 674-694. https://doi.org/10.2307/255939

Yeo, H. J., Pochet, C., \& Alcouffe, A. (2003). CEO reciprocal interlocks in French corporations. Journal of Management and Governance, 7, 87-108. https://doi.org/10.1023/A:1022442602193

Zhang, Y., \& Rajagopalan, N. (2004). When the known devil is better than an unknown god: an empirical study of the antecedents and consequences of relay CEO successions. Academy of Management, 47(4), 483-500. https://doi.org/10.2307/20159598

Zhang, Y., \& Rajagopalan, N. (2010). CEO succession planning: Finally at the center stage of the boardroom. Business Horizons, 53, 455-462. https://doi.org/10.1016/j.bushor.2010.05.003

\section{Notes}

Note 1. Staff Bulletin SLB 14E referenced in Conference Board April 2010

Note 2. Bradley Keoun, David Mildenberg and Ian Katz - November 23, 2009, BofA May Name Stopgap Chief If Board Needs More Time (Bloomberg)

Note 3. Consider, for instance, the Teco Energy's CEO from 1999 to 2004, Mr. Robert Fagan, received a severance amount of \$3.7 million pursuant to his pre-existing severance contract. St. Petersburg Times article: Fagan out as chairman of Teco II for details. In addition, see appendix 1 for the terms of the severance contracts between Teco Energy and Mr. Fagan. July 8, 2004.

Note 4. This database is now called Risk Metrics

\section{Appendix 1: Variable Definition and Explanations}

\section{Firm characteristics}

Firm age: Max (CRSP listing age, Compustat listing age)

Senior management turnover ${ }_{t+1}$ : A change of CFO, Chairman, Vice chairman and President as shown in IRRC (0/1) within one year of succession

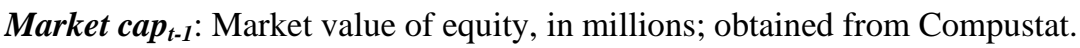

Total assets t-1 $_{\text {: }}$ in millions of dollars; obtained from Compustat.

Sales $_{t-1}$ : in millions of dollars; obtained from Compustat.

Log $_{\text {sales }} t:-\log \left(\right.$ sales $\left._{t-1}+1\right)$

Sales growth: The average of yearly sales growth rate of the past 3 year (i.e., sales growth is computed as from Compustat. 
Prior 1 year stock return $_{t-1} \%$ : The average market-adjusted daily stock returns. Adjusted by subtracting the daily return on the CRSP (NYSE, AMEX and Nasdaq) equal-weighted market index.

Institutional ownership t-1 $_{\text {: }}$ Percentage of the total shares outstanding held by institutional investors; data from TFN Institutional.

Industry adjusted Tobin's q: Tobin's q - median Tobin's q for the firm's Fama-French 48 industry; from Compustat Industry adjusted $\boldsymbol{R O A}_{t-1}$ : ROAt-1 minus Fama-French 48 industry median $\mathrm{ROA}_{\mathrm{t}-1}$

$\boldsymbol{R} \& \boldsymbol{D}$ to sales $\boldsymbol{s}_{t-1}: \mathrm{R} \& \mathrm{D}$ expense / Sales; form Compustat. Any missing value of R\&D expenditure is replaces with zero.

Capital expenditure to total assets $_{t-1}$ : Capital expenditure / Total assets; from Compustat.

Tobin's q: (Book value of total assets + Market value of equity - Book value of equity) /Book value of total assets; from Compustat

\section{Corporate governance characteristics}

Board size: Number of directors on the board; calculated from IRRC (Risk Metrics) Directors

Outside CEO-directors: Fraction of non-employee directors that are active CEOs; calculated from IRRC (Risk Metrics) Directors

CEO is chairman: CEO is also the chairman of the board; obtained from IRRC (1/0)

SOX: an indicator variable that equals to 1 if the unexpected turnover happened after the year 2001 and 0 if before 2001.

\section{CEO characteristics}

Death/illness: an indicator variable that equals to one if the outgoing CEO's departure is due to sudden death and illness, 0 if they are hired away. Manually collected information.

CEO age: CEO's age on fiscal year t; based on Execucomp data

New CEO turnover: A change of CEO as shown in ExecuComp (0/1) within 12 or 18 months of succession; based on Execucomp data

Number of turnovers: the total number of CEO turnover a firm experiences during the sample period 1996-2008; based on Execucomp data

CEO tenure: Number of years as CEO; calculated from Execucomp data

First time CEO: a binary variable that equals to 1 if the new $\mathrm{CEO}$ becomes the chief executive for the first time in his/her career and 0 otherwise; based on Execucomp data

On_board: an indicator variable that equals to 1 if the replacement CEO is an existing board member and 0 otherwise; based on IRRC data

Total compensation: ExecuComp data item TDC1 that includes sum of the CEO's salary, bonus, the value of stock options and restricted stock granted during the year, long-term incentive payouts, and other miscellaneous compensation

Cash compensation: ExecuComp data item TOTAL_CURR that includes sum of the CEO's salary and bonus

Equity based compensation: ExecuComp data item STOCK_AWARDS that includes the value of stock awards to the CEO

Equity compensation ratio: Equity based compensation / Total compensation. Data obtained from ExecuComp 